\title{
The Effect of Wheat Bran on the Total Apparent Digestibility of Dry Matter, NDF, ADF and CP in Goat Diets
}

\author{
R. Arias $^{1}$, M. G. Muro ${ }^{1}$, M. S. Trigo ${ }^{1}$, M. Eirin ${ }^{1}$, \\ D. Boyezuk ${ }^{1}$, C. A. Cordiviola ${ }^{1}$
}

\begin{abstract}
The aim of this study was to evaluate the effect of wheat bran in increasing amounts on the total apparent dry matter digestibility (DM), the fiber (NDF, ADF) and the protein (CP) in goat diets. Eight Criollo $x$ Nubian goats were used in a $4 \times 4$ Latin square experimental design. Four diets were provided: alfalfa hay $\left(\mathrm{D}_{0}\right)$; alfalfa hay + wheat bran (WB) $\left(0.5 \%\right.$ of BW/day) $\left(\mathrm{D}_{1}\right)$, alfalfa hay $+\mathrm{WB}\left(1 \%\right.$ of BW/day) $\left(\mathrm{D}_{2}\right)$ and alfalfa hay $+\mathrm{WB}(1.5 \%$ of $\mathrm{BW} /$ day $)$ $\left(\mathrm{D}_{3}\right)$. All the treatments consisted of alfalfa hay delivered ad libitum. In vivo total apparent digestibility of the DM intake and its fractions was calculated as a result of the difference between the ingested and excreted amounts in relation to the intake. Forage intake and the relation forage/concentrate decreased linearly $(\mathrm{p}<0.05)$ with the increase of the concentrate. Energy intake increased linearly $(\mathrm{p}<0.05)$ with larger amounts of WB. The total apparent digestibility of the ingested DM showed a significant linear increase $(p<0.05)$ with the increase of concentrate. The digestibility of NDF, ADF and CP registered no differences $(p>0.05)$ with the WB increase in the different treatments. We can conclude that the addition of WB in Criollo $x$ Nubian goats improved the total apparent digestibility of the ingested DM by replacing hay for concentrate, without altering NDF, ADF and CP fractions.
\end{abstract}

\section{Introduction}

Success in ruminant production is explained, to a significant extent, by the animal's capacity to digest fibrous vegetal materials. Microorganisms being able to degrade this kind of materials constitute a significant advantage over other animals in nature. However, high productivity levels cannot be sustained by forage only, therefore, agriculture products are often used in livestock farming (Russell y Rychlik, 2001).

Digestibility is mostly an inherent property of forage, whereas voluntary intake is a function of animals and the forage and environment under which they are fed (Coleman et al., 1999). To know the forage digestibility is not useful unless knowing the amount animals will ingest (Ørskov \& Ryle, 1990). The combination of both in vivo apparent digestibility of dry matter and dry matter intake results in the digestible dry matter intake. This value provides a more effective means for the assessment of feed potential than either of them separately (Coleman et al., 1999).

The extent to which concentrates affect fiber digestion may depend on their nature and proportion, as well as on the forage quality (Matejovsky $y$ Sanson, 1995). The incorporation of cereals in ruminant diets alters the rumen microflora, causing alterations in the fermentation patterns, and in the rumen and host animal's health (Russell \& Rychlik, 2001).

An increase of the total digestibility may be expected as a result of the incorporation of concentrate to the diet. The energy provided by the concentrate (fermentable carbohydrates) may reduce rumen $\mathrm{pH}$, the activity or number of cellulolytic bacteria, the rate of pasture fiber digestion and, therefore, the DM intake (Dixon \& Stockdale, 1999).

From the nutritional point of view, wheat bran can be considered a protein-energetic feed of intermediate values both in energy and protein. As it is a byproduct of flour extraction (starch), its energetic value fundamentally comes from the fiber of grain hulls. It is also a by-product with a low amount of $\mathrm{ADF}$, due to the low content of lignin and high content of hemicelluloses, compared to hay or other fiber feeds (FEDNA, 2018). The energetic value of wheat bran is $22 \%$ lower than the one found in corn grain; it is also lower in digestibility, for it has a lower amount of starch (Gallardo, 2006).

Extensive goat production is based on the use of forage. Alfalfa is considered a valued forage in goat feeding due to its high protein content and lower neutral detergent fiber (NDF) concentration, compared to other forage species. Its high content of high degradability soluble fiber and low content of NDF have a positive effect on dry matter intake

This article is published under the terms of the Creative Commons Attribution License 4.0

Author(s) retain the copyright of this article. Publication rights with Alkhaer Publications.

Published at: http://www.ijsciences.com/pub/issue/2019-10/

DOI: 10.18483/ijSci.2182; Online ISSN: 2305-3925; Print ISSN: 2410-4477 
(Rapetti, 2005). However, and due to the emergence of a more technical system, there is a tendency to the intensification and increase in the use of concentrate products to keep up with the high productivity levels (Castel et al., 2003).

Goats change their feeding behavior according to forage or concentrate availability, and they have the capacity of selecting food of high protein and digestibility levels (Provenza et al., 2003). When they receive supplements, dry matter intake decreases, and this is known as substitution rate (Kellaway \& Porta, 1993; Stock dale, 2000).

The incorporation of corn grain to ruminant feed increases the digestibility of the total ingested dry matter (Molina \& Alcaide et al., 2000, Fimbres et al., 2002), but it might decrease forage digestibility (Archimède et al., 1995). There is certain controversy on the effect of concentrate incorporation on the digestibility of forage components, according to the kind of concentrate, rumen $\mathrm{pH}$ and total and relative amount of different volatile fatty acids. For example, rich NDF feed such as hay and mature pastures induce $\mathrm{pH}$ between 6.5 and 8 , which is an optimum environment for celluloysis with predominant acetic acid (Aello \& Di Marco, 2000). There are numerous studies which prove that the incorporation of concentrate in diets has positive effects on forage digestibility, until it reaches certain proportion at which such effect is lost, or even negative (Chandramoni et al., 2000; Goetsch et al., 2001; Dung et al., 2005; Liu et al., 2005; Lefrileux et al., 2008). Many authors claim that ruminant diets with high content of starch reduce fiber digestion due to a microbial fermentation of non- structural carbohydrates, a reduction of rumen $\mathrm{pH}$ and a lower cellulolytic activity (Mould \& Orskov 1984; Kovacik et al., 1986; Grant \& Mertens, 1992; Garces-Yepez et al., 1997).

Moore et al., (2002) found no significant differences in rumen $\mathrm{pH}, \mathrm{NDF}$ and $\mathrm{ADF}$ digestibility in Boer goats and diets based on orchardgrass hay and a concentrate mixture (wheat bran, soy beans hull and corn gluten) incorporated to $1 \%$ of $\mathrm{BW}$.

Cantalapiedra et al., (2009) studied the effect of two diets on Granadina goats. These diets contained different forage/concentrate proportions (70/30 y $30 / 70$ ) consisting of alfalfa hay and a mixture of barley grain, gluten meal, wheat bran, and soy derivates. Studies showed an increase of total dry matter digestibility from $67 \%$ to $74 \%$ and of NDF from $55 \%$ to $67 \%$, in those diets with higher relative amount of concentrate. Contrarily, results showed no effect of diets on rumen $\mathrm{pH}$ and crude protein digestibility. Additionally, the incorporation of corn in increasing quantities, up to $1.5 \% \mathrm{DM} / \mathrm{BW}$, in alfalfa hay diets for crossbreed goats (Criollo $\mathrm{x}$ Nubian), decreased rumen $\mathrm{pH}$ under 6, affecting rumen degradability of forage fiber (Arias et al., 2013). Moreover, total NDF and ADF digestibility of the ingested diet was affected (Arias et al., 2015).

Goat feeding behavior is different from other ruminants' as regards diet selection and intake (Lu et $a l, 2005)$. For this reason, knowledge and information obtained of different species cannot be extrapolated to this particular one. The objective of this study was to evaluate the effect of increasing amounts of wheat bran on the total apparent digestibility of dry matter, $\mathrm{NDF}, \mathrm{ADF}$ and $\mathrm{CP}$, in goat diets.

\section{Method and Materials:}

This study was carried out in the Experimental Unit of the School of Forest and Agricultural Sciences of the National University of La Plata (UNLP).

\section{Animals \\ Eight five year old crossbreed (Criollo x Nubian) non-pregnant and dry goats of $44.64 \pm 1.49 \mathrm{~kg}$ of average BW were used. The experimental design was a duplicated $4 \times 4$ Latin square with 7 days of wash out in between terms. When determinations were carried out, the goats were put in individual boxes $(0.80 \mathrm{~m} \mathrm{x}$ $1.50 \mathrm{~m})$ with slatted wooden flooring, feeding troughs, slow feeders and automatic nipple drinkers with free access to water. Each animal's weight was registered at the beginning of each term.}

\section{Treatments}

Four diets containing alfalfa hay $\left(\mathrm{D}_{0}\right)$, alfalfa hay + wheat bran $\left(0.5 \%\right.$ of BW/day) $\left(\mathrm{D}_{1}\right)$, alfalfa hay + wheat bran $(1 \%$ of $\mathrm{BW} /$ day $)\left(\mathrm{D}_{2}\right)$ and alfalfa hay + wheat bran ( $1.5 \%$ of BW/day) $\left(\mathrm{D}_{3}\right)$ were provided. In all the treatments, alfalfa hay was delivered ad libitum. A 15-day adaptation period was implemented before sampling. The amount of wheat bran was delivered in an increasing manner, starting from $70 \mathrm{~g}$ per animal per day, until reaching each treatment's proportions at the beginning of the second week of the adaptation period. Diets were delivered once a day at 9 am each day. Alfalfa hay and wheat bran DM were determined by drying method (SOMCIC) to $90-95^{\circ} \mathrm{C}$ for 24 hours, (AOAC, 1995). Chemical composition of the ingredients used was determined according to AOAC (1995).

\section{Determination of DM total intake and in vivo total apparent digestibility of DM and its fractions (NDF, ADF and BW)}

The individual intake of DM and its fractions (NDF, $\mathrm{ADF} \mathrm{ME}$ and $\mathrm{CP}$ ) was determined by means of the difference between the delivered and rejected feed, during the 4 days of waste collection, after the 
adaptation period to the different diets. Stool was collected and quantified using a collecting bag system and a harness. Bags were emptied once a day and the total amount of stool was weighed. A subsample consisting of $10 \%$ of each animal's excreted material was frozen at $-20{ }^{\circ} \mathrm{C}$ for further chemical analyses. In vivo total apparent digestibility (IVTAD) of the DM intake and its fractions was calculated from the difference between the ingested and excreted feed in relation to the ingested, expressed in percent $(\%)$.

\section{Rumen pH determination}

The four goats were put a rumen fistula with permanent Bar Diamond Inc. cannulas of a 5" diameter. Rumen liquor was removed by cannula with vacuum pump at 0,2 and 4 hours after feed ration. Collected samples were filtered using four cheesecloth layers. $\mathrm{pH}$ was determined using a digital $\mathrm{pH}$ meter (Silver Cap pH 5045-3B) equipped with puncture electrode and thermoprobe calibrated with buffer solution at $\mathrm{pH} 4$ and 7. The area under the curve was calculated as the sum of partial areas defined by the absolute value of the deviation below $\mathrm{pH} 6$ and the real time interval between subsequent sampling, covering a 4 hours total span, accounted as $\mathrm{pH} \times$ sampling time/day. The average value of rumen $\mathrm{pH}$ and the time in hours with $\mathrm{pH}$ below 6 were calculated. Also, the effect of time after feed and the hour/treatment interaction were calculated by means of a repeated measure design.

\section{Chemical analyses}

Each stool sample consisted of subsamples from four days of collection later ground using a $1 \mathrm{~mm}$ mesh. To determine ADF and NDF, the technique of Van Soest (1991) later modified by Komarek (1994) was used, with a fiber analyzing equipment Ankom 200. Thermostable $\alpha$-amylase (Sigma A3306) and sodium sulfite were used for determining NDF. Total nitrogen was determined according to Kjeldahl-N method, (AOAC, 1995) multiplied by 6.25 to obtain the value of $\mathrm{CP}$.

\section{Statistical analyses}

To assess the effect of wheat bran increasing levels on the total dry matter intake (TDMI), of forage (DMFI), NDF (TNDFI), ADF (TADFI), metabolizable energy (TMEI), crude protein (TCPI), forage/concentrate relation $(\mathrm{F} / \mathrm{C})$, and the IVTAD of $\mathrm{DM}, \mathrm{NDF}, \mathrm{ADF}$ and $\mathrm{CP}$ of the different diets, we used the model found below:

$\mathrm{Y}=\mu+\mathrm{T}+\mathrm{EU}+\mathrm{P}+\mathrm{e}$

$\mathrm{Y}$ : independent variable

$\mu$ : trials general mean

T: treatment

EU: experimental unit

P: period e: error

Data were analyzed by MIXED SAS procedure (SAS, 2004) for a Latin $4 x 4$ replicated square, using a mixed model which included the fixed sampling effect (treatment, period) and the random effect of the animal. Polynomial orthogonal contrasts were used to determine the linear effects $(\mathrm{L})$, quadratic $(\mathrm{Q})$ and cubic (C) of increasing levels of wheat bran. Tuckey test was used for the means comparison analysis. Significant differences were considered with a value $\mathrm{p}<0.05$ and the tendencies with a $\mathrm{p}$ value between 0.05 y 0.10 .

\section{Results and Discusion}

After assessment of the effect of increasing amounts of wheat bran using polynomial orthogonal contrasts, no significant differences were observed on the TDMI, TCPI, TNDFI $(p>0.05)$. A linear decrease $(p<0.05)$ of FDMI and TADFI was evidenced. The increase of the concentrate in the ration caused a linear decline $(\mathrm{p}<0.05)$ of the $\mathrm{F} / \mathrm{C}$, and registered an evident substitutive effect of alfalfa hay by the flour industry by-product. TMEI increased linearly $(p<0.05)$ with larger amounts of concentrate. Using the means analysis, we proved that FDMI of $\mathrm{D}_{2} \mathrm{y} \mathrm{D}_{3}$ was significantly lower $(\mathrm{p}<0.05)$ than $\mathrm{D}_{0}$. Diets $\mathrm{D}_{1}$, $D_{2}$ and $D_{3}$ registered the highest intake of metabolizable energy $(\mathrm{p}<0.05)$ with respect to $\mathrm{D}_{0}$ (Table 2).

As regards the IVTAD of the ingested DM, a significant linear increase $(p<0.05)$ was observed with the increase of the concentrate. Digestibility of fractions NDF, ADF and CP verified no significant differences $(p>0.05)$ with the increase of wheat bran amount in the different treatments (Table 3 )

Average rumen $\mathrm{pH}$ decreased linearly $(\mathrm{p}=0.001)$ with wheat bran amounts between 0 and $1.5 \% \mathrm{DM} / \mathrm{BW}$. Diet $\mathrm{D}_{3}$ registered the lowest average $\mathrm{pH}$ compared to the rest of the treatments (Figure 1). The areas under the curve of $\mathrm{pH}$ threshold 6 and hours with $\mathrm{pH}$ below 6 were value 0 , because rumen $\mathrm{pH}$ values were above 6 in the 4 hour span after feed. By means of a repeated measure in time design, an effect of the hours $(p=0.001)$ was verified in the daily evolution of rumen $\mathrm{pH}$. From the two hours after the ration intake, a significant interaction was observed $(\mathrm{p}=0.04)$ hour/treatment on rumen $\mathrm{pH}$ (Figure 2).

As Provenza et al., (2003) claimed, goats changed their feeding behavior according to the forage or concentrate availability, accepting and ingesting the total amount of the different quantities of tested bran. Goats receiving supplement caused dry matter intake of the forage to decrease due to a substitutive effect 
of alfalfa hay by the flour industry waste product, as Kellaway \& Porta (1993) and Stockdale (2000) stated. The highest energy intake in diets with increasing amounts of wheat bran is the result of this flour by-product containing a high energy value, given by grain hulls.

From the nutritional point of view, wheat bran can be defined as a protein-energetic type of feed, with intermediate values both in energy and proteins (Gallardo, 2006). For this reason, CP values remained constant. The lowest ADF intake in diets with wheat bran was the result of it containing $62.7 \%$ less of this fraction compared to alfalfa hay (FEDNA, 2018).

As Dixon \& Stockdale (1999) stated, the incorporation of concentrates to the diet increased the total dry matter digestibility and had positive effects on the fiber digestibility of the ingested diet (Chandramoni et al., 2000; Goetsch et al., 2001; Dung et al., 2005; Liu et al., 2005; Lefrileux et al., 2008). Although there were numeric differences, NDF digestibility of the treatment with the highest amount of wheat bran was $8.6 \%$ higher than the control diet, contrarily to the study of Arias et al. (2013, 2015), which evidenced a decrease of the fiber digestibility after the incorporation of corn to alfalfa hay diets.

The incorporation of wheat bran to the different treatment caused a decreasing effect of the rumen $\mathrm{pH}$ after intake (Mould \& Orskov 1984; Kovacik et al., 1986; Grant \& Mertens, 1992; Garces-Yepez et al., 1997). In addition, the values registered in this study were above 6 (Moore et al., 2002; Cantalapiedra et al., 2009). Such effect might explain the lack of negative effects on fiber digestibility, probably by contributing to create an optimum mean for cellulolysis in general, and the predominance of acetic acid in particular (Aello \& Di Marco, 2000).

\section{Conclusion}

Therefore, we can conclude that the incorporation of wheat bran to an alfalfa hay diet ad libitum in Criollo $x$ Nubian goats, in the tested quantities, has improved the total apparent digestibility of the dry matter intake by an evident substitutive effect of the hay by the concentrate, without affecting NDF, ADF and CP fractions.

\section{Bibliography:}

1. Coleman, S.W., Lippke, H. y Gill, M. 1999. Estimating the nutritive potential of forages. In: Nutritional Ecology of Herbivores (Ed.H.J. Jung y G.C. Fahey), pp. 647.

2. Dixon, R. M., and C. R. Stockdale. 1999. Associative effects between forages and grains: consequences for feed utilization. Aust. J. Agric. Res. 50:757-773.

3. Lu, C. D., J. R. Kawas, and O. G. Mahgoub. 2005. Fibre digestión and utilization in goats. Small Rumin. Res. 60:4552 .
4. Aello M., O. Di Marco. 2000. Digestión y metabolismo ruminal. In Nutrición animal. (ed) Universidad Nacional de Mar del Plata. Facultad de Ciencias Agrarias. Balcarce, Argentina. pp: 65-99.

5. AOAC. 1995. Dry mater in Animal Feed. Method number 934.01. In: Official Methods of Analysis of AOAC International. 16th edn. vol. I. Association of Official Analytical Chemists, Arlington, VA, USA, pp, I (Chapter 4).

6. AOAC. 1995. Protein (Crude) in Animal Feed. Method number 990.03. In: Official Methods of Analysis of AOAC International. 16th edn. vol. I. Association of Official Analytical Chemists, Arlington, VA, USA, pp, 10-11 (Chapter 4).

7. Archimède, H., D. Sauvant, J. Hervieu, C. Poncet \& M Dorleans. 1995. Digestive interactions in the ruminant relationships between whole tract and stomach evaluation. Anim. Feed Sci. Technol. 54:327-340.

8. Arias, R., M. G. Muro, C.A. Cordiviola, M.S. Trigo, M. Brusa, R. A. Lacchini. 2013. Incidencia de la proporción de maíz sobre la degradabilidad in situ de heno de alfalfa en dietas para caprinos. Revista de la Facultad de Agronomía, La Plata. 112 (2) 62-67.

9. Arias R.O, M.G Muro, C.A Cordiviola; A.C Cattáneo; M.S Trigo y R.A Lacchini. 2015. Efecto de la suplementación con grano de maíz sobre la digestibilidad in vivo del heno de alfalfa en caprinos. Revista de la Facultad de Agronomía. La Plata. 114 (1): 44-48

10. Komarek, A. R., J. B. Robertson \& P. J. Van Soest. 1994 Comparison of the filter bag technique to conventional filtration in the Van Soest Analysis of 21 feeds. In: Proc. Natl. Conf. on Forage Quality, Evaluation and Utilization, Lincoln, NE. pp.78.

11. Cantalapiedra-Hijar, G., D. R. Yáñez-Ruiz, A. I. MartínGarcía \& E. Molina-Alcaide. 2009. Effects of forage: concentrate ratio and forage type on apparent digestibility, ruminal fermentation, and microbial growth in goats. J Anim Sci. 87: 622-631

12. Castel, J. M., Y. Mena, M. Delgado-Pertíñez, J. Camúñez, J. Basulto, F. Caravaca, J. L. Guzmán \& M. J. Alcalde. 2003. Characterisation of semi extensive goat production systems in Southern Spain. Small Rumin. Res. 47: 1-11.

13. Chandromoni, S., B. Jadhao \& M.Y. Tiwari. 2000. Energy metabolism whit particular reference to methane production in Muzaffarmagari sheep fed rations varyring in roughage to concentrate ratio. Animal Feed Science and Technology. 83: 287-300.

14. Dung, N.T. \& I. Mui. 2005. Effect of replacing a commercial concentrate with cassava (Manihot esculenta Crantz) on the performance of growing goats. Animal Feed Science and Technology 21: 197-204

15. FEDNA. 2018. Fundación Española para el Desarrollo de la Nutrición Animal. Tablas de composición y valor nutritivos de alimentos para la fabricación de piensos compuestos. 502 pp.

16. Fimbres, H., J. R. Kawas, G. Hernandez-Vidal, J. F. PiconRubio \& C. D. Lu. 2002. Nutrient intake, digestibility, mastication and ruminal fermentation of lambs fed finishing ration with various forage levels. Small Rumin. Res. 43: 275281.

17. Gallardo, M. 2006. XXI Curso internacional de lechería para profesionales de América Latina. 153-162.

18. Garces-Yepez, P., W. E. Kunkle, D. B. Bates, J. E. Moore, W. W.Thatcher \& L. E. Sollenberger. 1997. Effects of supplemental energy source and amount on forage intake and performance by steers and intake and diet digestibility by sheep. J. Anim. Sci. 75:1918-1925.

19. Goetsch A.L., G. Detweiler, T. Sahlu, R. Puchala \& L.J. Dawson. 2001. Dairy goat performance with different dietary concentrate levels late lactation. Small Rumin. Res. 41: 117-12.

20. Grant, R.J. \& D.R. Mertens.1992. Development of buffer of $\mathrm{pH}$ effects on fiber systems for $\mathrm{pH}$ control and evaluation digestion in vitro. J. Dairy Sci. 75:1581-1587. 
21. Hofman, R. R. 1989. Evolutionary steps of ecophysiological adaptation and diversification of ruminants: a comparative view of their digestive system. Oecologia 78:443-457.

22. Kellaway, R., \& S. Porta. 1993. Feeding concentrates supplements for dairy cows. Dairy Research and Development Corporation. Australia. 176 pp.

23. Kovacik, A.M., S.C. Loerch \& B.A. Dehority.1986. Effect of supplemental sodium bicarbonate on nutrient digestibility and ruminal pH measured continuously. J. Anim. Sci. 62:226234

24. Lefrileux Y., P. Morand-Fehr \& A. Pommare. 2008. Capacity of high milk yielding goats for utilizing cultivated pasture. Small Rumin. Res. 77: 113-126.

25. Liu X., Z. Wang \& F. Lee. 2005. Influence of concentrate level on dry matter intake, $\mathrm{N}$ balance, nutrient digestibility, ruminal outflow rate, and degradability in sheep. Small Rumin. Res. 58: 55-62.

26. Matejovsky, K. M. \& D. W. Sanson. 1995. Intake and digestion of low-, medium-and high- quality grass hays by lambs receiving increasing levels of corn supplementation. J. Anim. Sci. 73:2156-2163.

27. Molina-Alcaide, E., A. I. Martín-García \& J. F. Aguilera. 2000. A comparative study of nutrient digestibility, kinetics of degradation and passage and rumen fermentation pattern in goats and sheep offered good quality diets. Livest. Prod. Sci. 64: $215-222$

28. Mould, F. L. \& E. R. Orskov. 1984. Manipulation of rumen fenid $\mathrm{pH}$ and influence on cellulose in sacco, dry matter degradation and the run microflora of sheep offered either hay or concentrate. Animal Feed Science and Technology.10:1-14

29. Moore, J.A., M.H. Poore, J.M. Luginbuhl. 2002. By-product feeds for meat goats: Effects on digestibility, ruminal environment, and carcass characteristics. J. Anim. Science.80:1752-1758.

30. Ørskov, E.R. y Ryle, M. 1990. Energy Nutrition in Ruminants. Elsevier Applied Science, Londres y Nueva York. 695. American Society of Animal Science, Illinois, USA.

31. Provenza, F.D., J.J. Villalba, L. E. Dziba, S.B. Atwood \& R.E. Banner. 2003. Linking herbivore experience, varied diets, and plant biochemical diversity. Small Ruminant Research. 49:257-274.

32. Rapetti, L., L. Bava, A. Tamburini \& G.M. Crovetto. 2005. Feeding behaviour, digestibility, energy balance and productive performance of lactating goats fed forage-based and forage-free diets. Italian. Journal of Animal Science. 4:71-83.

33. Russell, J. B. \& J. L. Rychlik. 2001. Factors that alter rumen microbial ecology. Science 292:1119-1122.

34. SAS Institute Inc. 2004. SAS On line Doc* 9.1.3. Cary, NC: SAS Institute. Inc.

35. Van Soest, P.J, J.B. Robertson \& B.A. Lewis. 1991. Methods for dietary fiber neutral detergent fiber and non-starch polysaccharids in relation to animal nutrition. J. Dairy Sc.74:3583-3597.

Table 1. Chemical composition of the feed used.

\begin{tabular}{lcc}
\hline Item & Alfalfa & Wheat bran \\
\hline DM (\%) & 87,0 & 89,0 \\
OM (\%) & 91,9 & 98,7 \\
CP (\%) & 13,7 & 15 \\
ME (Mcal) & 2,02 & 2,54 \\
NDF (\%) & 58,87 & 51 \\
ADF (\%) & 44,03 & 19 \\
\hline
\end{tabular}

*Biochemistry and Phyto-chemistry Lab of the School of Forest and Agricultural Sciences of La Plata. UNLP. Animal Nutrition Lab of the School of Veterinary Sciences of UNLP.

DM: Dry matter.

OM: Organic Matter.

CP: Crude Protein

ME: Metabolizable Energy.

NDF: Neutral Detergent Fiber.

ADF: Acid Detergent Fiber. 
Table 2. Polynomial orthogonal contrasts to determine linear, quadratic and cubic effects, and comparison means analysis to evaluate the incidence of supplementation with wheat bran on TDMI, FDMI, TNDFI, TADFI, TCPI, TMEI and relation F/C.

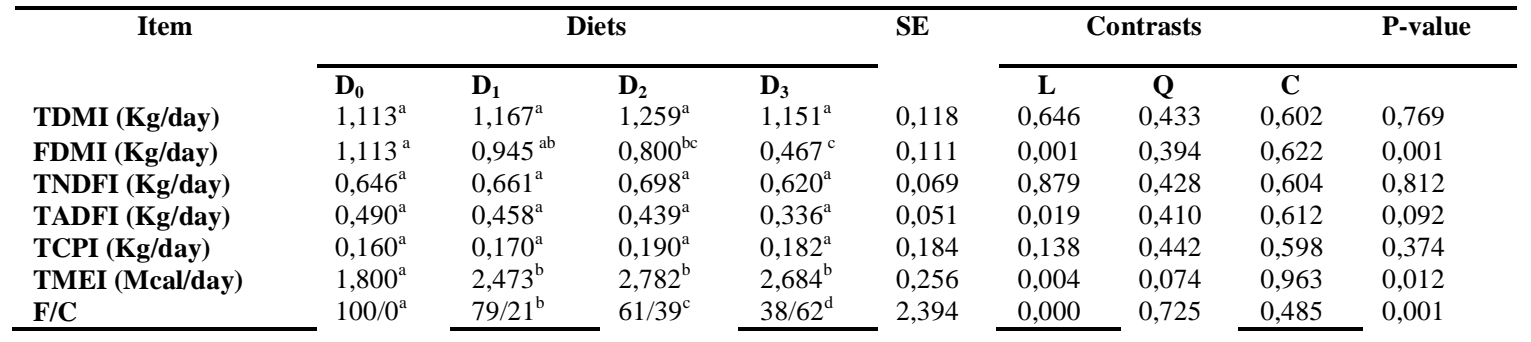

$\mathrm{D}_{0}: 100 \%$ alfalfa hay ad libitum.

$\mathrm{D}_{1}: 0.5 \%$ of BW of wheat bran and alfalfa ad libitum in the diet.

$\mathrm{D}_{2}: 1 \%$ of BW of wheat bran and alfalfa ad libitum in the diet.

$\mathrm{D}_{3}: 1.5 \%$ of BW of wheat bran and alfalfa ad libitum in the diet.

TDMI: Total dry matter intake per day expressed in Kg per day.

FDMI: Forage dry matter intake expressed in $\mathrm{Kg}$ per day.

TNDFI: Total intake of NDF expressed in Kg per day.

TADFI: Total intake of ADF expressed in Kg per day.

TCPI: Total intake of Crude Protein expressed in $\mathrm{Kg}$ per day.

TMEI: Total Intake of Metabolizable Energy expressed in Mcal per day.

F/C: forage-concentrate relation of the ingested diet, according to treatment.

SE: Standard Error.

L: Probability value associated to a linear effect of the supplementation level with wheat bran in a polynomial orthogonal contrast.

Q: Probability value associated to a quadratic effect of the supplementation level with wheat bran in a polynomial orthogonal contrast.

C: Probability value associated to a cubic effect of the supplementation level with wheat bran in a polynomial orthogonal contrast.

$P$ value: Same letters indicate non-significant differences for a $5 \%$ of probability.

Table 3. Polynomial orthogonal contrasts to determine linear, quadratic and cubic effects, and comparison means analysis to evaluate the incidence of supplementation with wheat bran on IVTAD, DM, OM, ADF, NDF and CP.

\begin{tabular}{|c|c|c|c|c|c|c|c|c|c|}
\hline \multirow[t]{2}{*}{ Item } & \multicolumn{4}{|c|}{ Diets } & \multirow[t]{2}{*}{ SE } & \multicolumn{3}{|c|}{ Contrasts } & \multirow[t]{2}{*}{ P-value } \\
\hline & $\mathbf{D}_{0}$ & $\mathbf{D}_{1}$ & $\mathbf{D}_{2}$ & $\mathbf{D}_{3}$ & & $\mathbf{L}$ & $\mathbf{Q}$ & $\mathbf{C}$ & \\
\hline IVDMTAD (\%) & $56,89^{\mathrm{a}}$ & $56,20^{\mathrm{a}}$ & $61,60^{\mathrm{a}}$ & $63,20^{\mathrm{a}}$ & 2,988 & 0,029 & 0,631 & 0,354 & 0,119 \\
\hline IVNFDTAD $(\%)$ & $55,16^{\mathrm{a}}$ & $53,80^{\mathrm{a}}$ & $57,43^{\mathrm{a}}$ & $60,03^{\mathrm{a}}$ & 3,178 & 0,127 & 0,449 & 0,606 & 0,359 \\
\hline IVADFTAD $(\%)$ & $55,26^{\mathrm{a}}$ & $56,98^{\mathrm{a}}$ & $56,71^{\mathrm{a}}$ & $54,63^{\mathrm{a}}$ & 3,185 & 0,846 & 0,448 & 0,987 & 0,887 \\
\hline IVCPTAD $(\%)$ & $67,29^{\mathrm{a}}$ & $65,88^{a}$ & $68,14^{\mathrm{a}}$ & $70,59^{a}$ & 2,380 & 0,146 & 0,258 & 0,528 & 0,556 \\
\hline
\end{tabular}

$\mathrm{D}_{0}: 100 \%$ alfalfa hay ad libitum.

$\mathrm{D}_{1}: 0.5 \%$ of BW of wheat bran and alfalfa ad libitum in the diet.

$\mathrm{D}_{2}: 1 \%$ of BW of wheat bran and alfalfa ad libitum in the diet.

$\mathrm{D}_{3}: 1.5 \%$ of BW of wheat bran and alfalfa ad libitum in the diet.

IVDMTAD: total apparent digestibility in vivo of dry matter, expressed in percent.

IVNFDTAD: total apparent digestibility in vivo of neutral detergent fiber, expressed in percent.

IVADFTAD: total apparent digestibility in vivo of acid detergent fiber, expressed in percent..

IVCPTAD: total apparent digestibility in vivo of crude protein, expressed in percent.

SE: Standard Error.

L: Probability value associated to a linear effect of the supplementation level with wheat bran in a polynomial orthogonal contrast.

Q: Probability value associated to a quadratic effect of the supplementation level with wheat bran in a polynomial orthogonal contrast.

C: Probability value associated to a cubic effect of the supplementation level with wheat bran in a polynomial orthogonal contrast.

$P$ value: Same letters indicate non-significant differences for a $5 \%$ of probability. 
Graphic 1: Average rumen $\mathrm{pH}$ according to treatment.

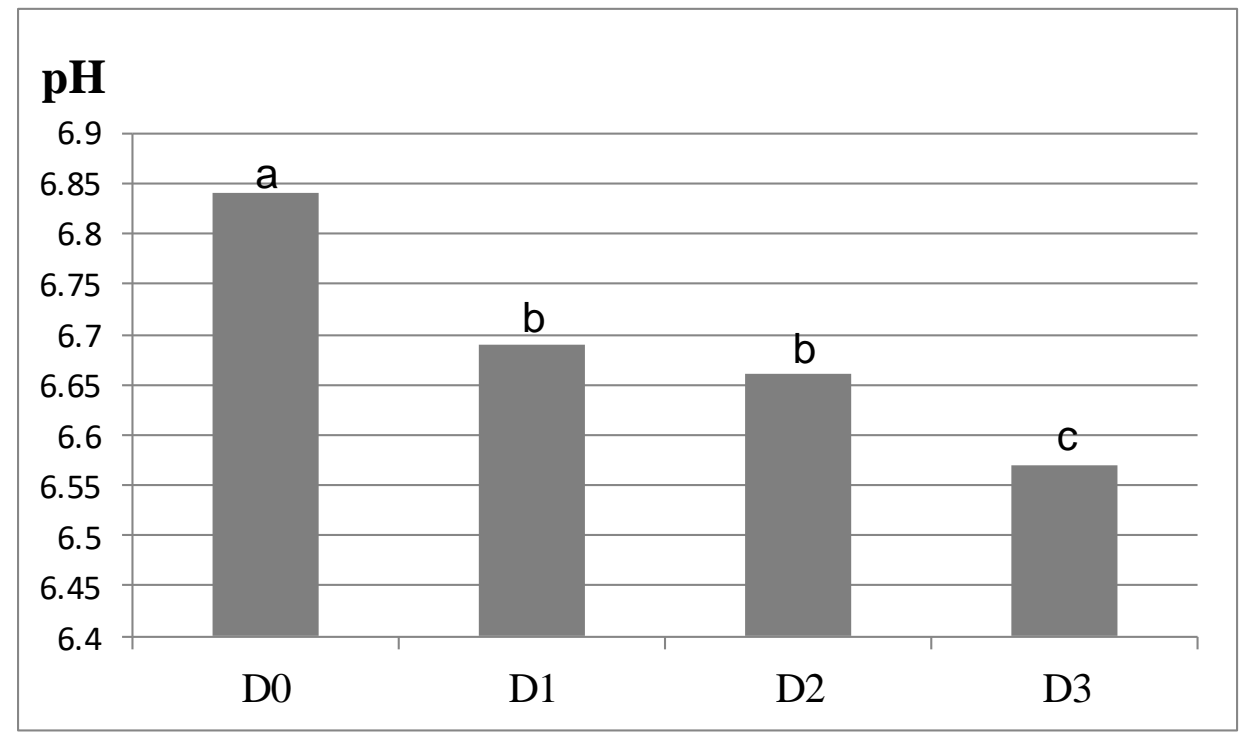

$\mathrm{D}_{0}: 100 \%$ alfalfa hay ad libitum.

$\mathrm{D}_{1}: 0.5 \%$ of $\mathrm{BW}$ of wheat bran and alfalfa ad libitum in the diet.

$\mathrm{D}_{2}: 1 \%$ of BW of wheat bran and alfalfa ad libitum in the diet.

$\mathrm{D}_{3}: 1.5 \%$ of $\mathrm{BW}$ of wheat bran and alfalfa ad libitum in the diet.

Graphic 2. Rumen pH evolution in the 4 hours after feeding, according to treatment.

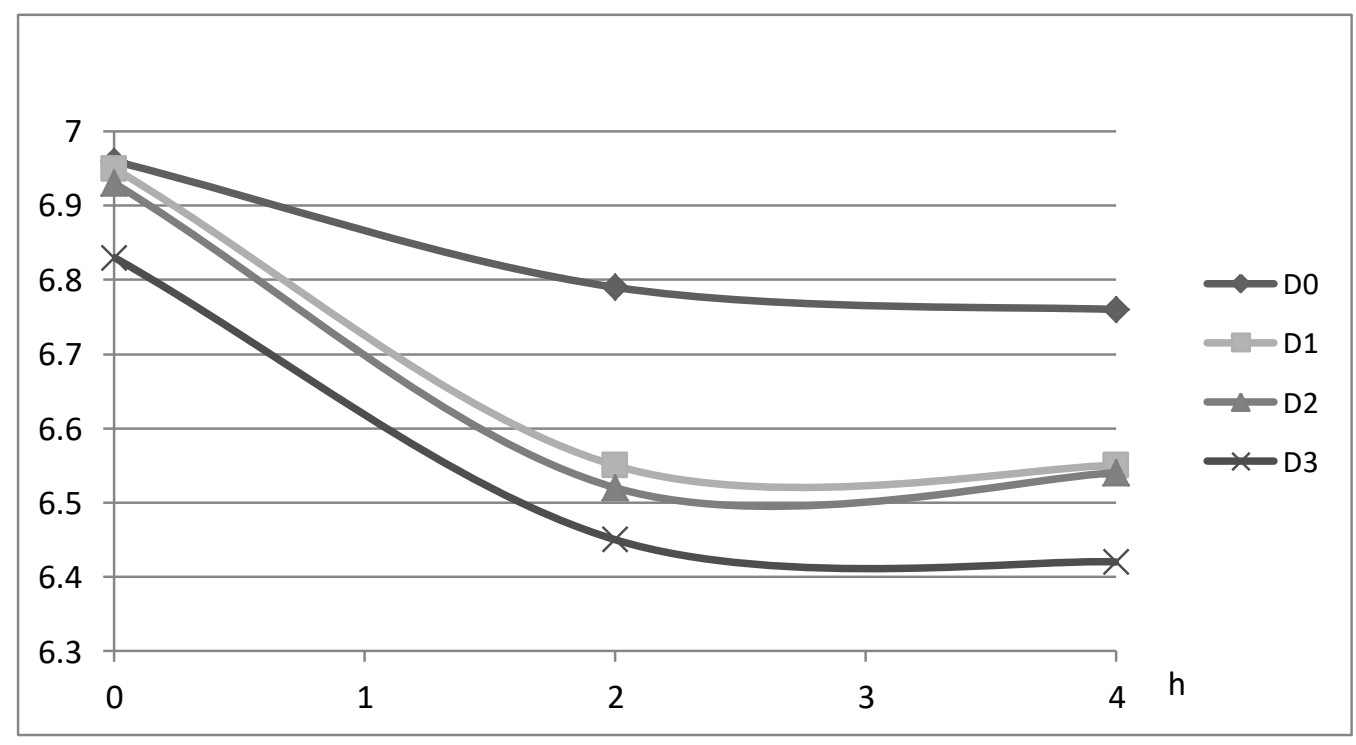

$\mathrm{D}_{0}: 100 \%$ alfalfa hay ad libitum.

$\mathrm{D}_{1}: 0.5 \%$ of BW of wheat bran and alfalfa ad libitum in the diet.

$\mathrm{D}_{2}: 1 \%$ of $\mathrm{BW}$ of wheat bran and alfalfa ad libitum in the diet.

$\mathrm{D}_{3}: 1.5 \%$ of BW of wheat bran and alfalfa ad libitum in the diet. 